\title{
High tolerance of microzooplankton to ocean acidification in an Arctic coastal plankton community
}

\author{
N. Aberle ${ }^{1}$, K. G. Schulz ${ }^{2}$, A. Stuhr ${ }^{2}$, A. M. Malzahn ${ }^{1,3}$, A. Ludwig ${ }^{2}$, and U. Riebesell ${ }^{2}$ \\ ${ }^{1}$ Biologische Anstalt Helgoland, Alfred Wegener Institute, Helmholtz Centre for Polar and Marine Research, Kurpromenade, \\ 27498 Helgoland, Germany \\ ${ }^{2}$ GEOMAR - Helmholtz Centre for Ocean Research, Düsternbrooker Weg 20, 24105 Kiel, Germany \\ ${ }^{3}$ Sultan Qaboos University, College of Agricultural and Marine Sciences, Dept. of Marine Sciences and Fisheries, \\ P.O. Box 34, 123 Al-Khoud, Sultanate of Oman
}

Correspondence to: N. Aberle (nicole.aberle-malzahn@awi.de)

Received: 31 July 2012 - Published in Biogeosciences Discuss.: 20 September 2012

Revised: 3 February 2013 - Accepted: 11 February 2013 - Published: 5 March 2013

\begin{abstract}
Impacts of ocean acidification (OA) on marine biota have been observed in a wide range of marine systems. We used a mesocosm approach to study the response of a high Arctic coastal microzooplankton community during the post-bloom period in Kongsfjorden (Svalbard) to direct and indirect effects of high $p \mathrm{CO}_{2} / \mathrm{low} \mathrm{pH}$. We found almost no direct effects of OA on microzooplankton composition and diversity. Both the relative shares of ciliates and heterotrophic dinoflagellates as well as the taxonomic composition of microzooplankton remained unaffected by changes in $p \mathrm{CO}_{2} / \mathrm{pH}$. Although the different $p \mathrm{CO}_{2}$ treatments affected food availability and phytoplankton composition, no indirect effects (e.g. on the total carrying capacity and phenology of microzooplankton) could be observed. Our data point to a high tolerance of this Arctic microzooplankton community to changes in $p \mathrm{CO}_{2} / \mathrm{pH}$. Future studies on the impact of $\mathrm{OA}$ on plankton communities should include microzooplankton in order to test whether the observed low sensitivity to OA is typical for coastal communities where changes in seawater $\mathrm{pH}$ occur frequently.
\end{abstract}

\section{Introduction}

Since the beginning of the industrial revolution, the oceans have absorbed ca. $30 \%$ of anthropogenic $\mathrm{CO}_{2}$ (Sabine et al., 2004), and oceans thus serve as one of the largest sinks for anthropogenic $\mathrm{CO}_{2}$, which in turn affects the marine carbonate system. The on-going increase in atmospheric $p \mathrm{CO}_{2}$ re- sults in decreasing seawater $\mathrm{pH}$ and carbonate ion $\left(\mathrm{CO}_{3}^{2-}\right)$ and increasing bicarbonate $\left(\mathrm{HCO}_{3}^{-}\right)$and $\mathrm{CO}_{2}$ concentrations. Especially the predicted drop in $\mathrm{pH}$, in the following referred to as "ocean acidification (OA)", is considered to affect a variety of biological and biogeochemical processes in the oceans with potentially far-reaching consequences on the community and ecosystem level (Riebesell et al., 2007). In this study, we wanted to test whether Arctic coastal plankton communities will be in any way affected by high $p \mathrm{CO}_{2} / \mathrm{low}$ $\mathrm{pH}$ and thus susceptible to ocean acidification.

Microzooplankton (MZP in the following) include heterotrophic protozoa and metazoa in the plankton within a size range between 20 and $200 \mu \mathrm{m}$. In this study we focussed on heterotrophic dinoflagellates and ciliates since these were numerically the most important MZP components and they are considered as major phytoplankton consumers worldwide (Calbet and Landry, 2004; Sherr and Sherr, 2007). Bacterivorous protozoa (e.g. heterotrophic nanoflagellates) were not included in our analysis but are presented by Brussaard et al. (2013). Today, there is strong evidence that MZP play a pivotal role in suppressing phytoplankton blooms in temperate (Johansson et al., 2004; Aberle et al., 2007) and cold waters (Levinsen and Nielsen, 2002; Seuthe et al., 2011). MZP usually show a rapid numerical response to changes in food availability, and the occurrence of specific species in the plankton can be directly linked to specific prey organisms (Loeder et al., 2011). MZP can thus be strongly bottomup controlled since their development can be directly linked to food availability. But at times when mesozooplankton 
abundance is high, top-down control (e.g. by copepods or meroplanktonic larvae) plays a crucial role in suppressing MZP abundance considerably (Levinsen and Nielsen, 2002).

Changes in $p \mathrm{CO}_{2}$ are known to affect consumers indirectly via changes, e.g. in food availability, phytoplankton community structure, size classes and stoichiometry (Suffrian et al., 2008; Feng et al., 2009; Rossoll et al., 2012). On the other hand MZP are known for a direct $\mathrm{pH}$ sensitivity (Hinga, 2002; Pedersen, 2003), and a drop in seawater $\mathrm{pH}$ as a result of increasing $p \mathrm{CO}_{2}$ could directly affect the physiology of both autotrophic and heterotrophic protists by changing, e.g. intracellular $\mathrm{pH}$, membrane potentials and enzyme activities (Nielsen et al., 2010).

To investigate the impact of OA on a natural Arctic plankton community, a mesocosm experiment was conducted in Kongsfjorden, Svalbard, over a period of about one month in June/July 2010. The initiation of the phytoplankton spring bloom in the fjord starts already under the ice cover, culminating between April and early June after ice break-up (Eilertsen et al., 1989; Seuthe et al., 2011). After the spring bloom, phytoplankton remain moderately high during late spring and summer (Hop et al., 2002). MZP are underinvestigated in the Kongsfjorden so far, but there is profound evidence that ciliates and heterotrophic dinoflagellates play an important role as trophic intermediaries in Arctic plankton communities (Seuthe et al., 2011).

In the present study we hypothesized the following:

1. direct effects of high $p \mathrm{CO}_{2}$ will alter MZP community composition and diversity, and

2. indirect effects of high $p \mathrm{CO}_{2}$ by changes in food availability and phytoplankton composition will alter the carrying capacity and phenology of MZP.

\section{Methods}

In summer 2010 nine polyethylene mesocosms $\left(\sim 50 \mathrm{~m}^{3}\right.$, $17 \mathrm{~m}$ long) were deployed at $78^{\circ} 56^{\prime} 2^{\prime \prime} \mathrm{N}, 11^{\circ} 53^{\prime} 6^{\prime \prime} \mathrm{E}$ in Kongsfjorden, Svalbard, from 28 May 2010 until 7 July 2010. The mesocosms were moored, and each mesocosm was filled with nutrient-poor, post-bloom seawater from the fjord passed through a net of $3 \mathrm{~mm}$ mesh-size during filling. $\mathrm{CO}_{2}$-enriched seawater was injected into the mesocosms to achieve a gradient in $p \mathrm{CO}_{2}$ levels ranging between 175 and $1085 \mu$ atm respectively from ambient post-bloom conditions to 21 st century predictions (see Table A1 for details on $\mathrm{pH}$ and $p \mathrm{CO}_{2}$ during the course of the experiment). Three different levels were defined: low $p \mathrm{CO}_{2}$ level of 175$250 \mu \mathrm{atm}$; intermediate $p \mathrm{CO}_{2}$ level of 340-600 $\mu \mathrm{atm}$; and high $p \mathrm{CO}_{2}$ level of $675-1085 \mu \mathrm{atm}$ where the $p \mathrm{CO}_{2}$ values given are calculated as the mean $p \mathrm{CO}_{2}$ from day $8-27$. On day 13 , nutrients were added to all $p \mathrm{CO}_{2}$ treatments to ensure a sufficient nutrient supply for bloom development. The added nutrient concentrations were $\sim 5 \mu \mathrm{M}$ nitrate, $\sim 0.3 \mu \mathrm{M}$ phosphate and $\sim 2.5 \mu \mathrm{M}$ silicate. A detailed description of the mesocosm design, the deployment logistics, the methodology of $\mathrm{CO}_{2}$ enrichment and the maintenance of the mesocosms throughout the duration of the experiment is given in Riebesell et al. (2012).

\subsection{Microzooplankton sampling and identification}

Seawater samples for MZP enumeration were taken once a week by a depth-integrating water sampler (depth integration: $0-12 \mathrm{~m}$ water depth). A total of $250 \mathrm{~mL}$ of seawater were transferred to brown-glass bottles and fixed with acidic Lugol's iodine ( $2 \%$ final concentration). A total of $100 \mathrm{~mL}$ of each sample were transferred to sedimentation chambers, and MZP were counted by the inverted microscope method (Utermöhl, 1958) at a $200 \times$ magnification with a Zeiss Axiovert 135. The whole area of the bottom plate was counted for each sample in order to guarantee comparability of the counting method both at periods of high and low MZP abundance. Most dinoflagellates were considered as heterotrophic since most species found in the samples are characterized by obligate or optional heterotrophic feeding modes. Only some small, chloroplast-bearing dinoflagellates were considered as predominantly autotrophic and included into the phytoplankton. MZP were identified to the lowest possible taxonomic level (species or genus level) according to Kahl (1932), Foissner et al. (1995), Strüder-Kypke et al. (2002), Tomas (1996) and Scott (2005). For biovolume calculations geometric proxies were used according to Hillebrand et al. (1999), and carbon biomass was calculated using the conversion factors given in Putt and Stoecker (1989). Diversity was measured by the Shannon-Wiener function $\left(H^{\prime}\right.$; $\log _{\mathrm{e}}$ ) (Shannon and Weaver, 1963).

\subsection{Phytoplankton sampling and identification}

A total of $100 \mathrm{~mL}$ water sample from a depth-integrating water sampler (depth integration: 0-12 $\mathrm{m}$ water depth) were filled in brown-glass bottles and fixed with alkaline Lugol's iodine (1\% final concentration). The counting was performed after Utermöhl (1958) with an inverted microscope (Zeiss Axiovert 100). Cells bigger than $12 \mu \mathrm{m}$ were counted on the half bottom area at 200-fold magnification and cells less than $12 \mu \mathrm{m}(\sim 5-12 \mu \mathrm{m})$ on two to four stripes at 400 -fold magnification. The settling volume was $25 \mathrm{~mL}$. For identification Tomas (1996), Hoppenrath et al. (2009) and Kraberg et al. (2010) were used. The biovolumes were calculated after Olenina et al. (2006), and for transformation to carbon the equations of Menden-Deuer and Lessard (2000) were used.

\subsection{Chlorophyll measurements}

A total of $250-500 \mathrm{~mL}$ of seawater were sampled and filtered onto GF/F for chlorophyll $a$ analysis. Filters were stored frozen for at least $24 \mathrm{~h}$ and homogenized in $90 \%$ acetone 

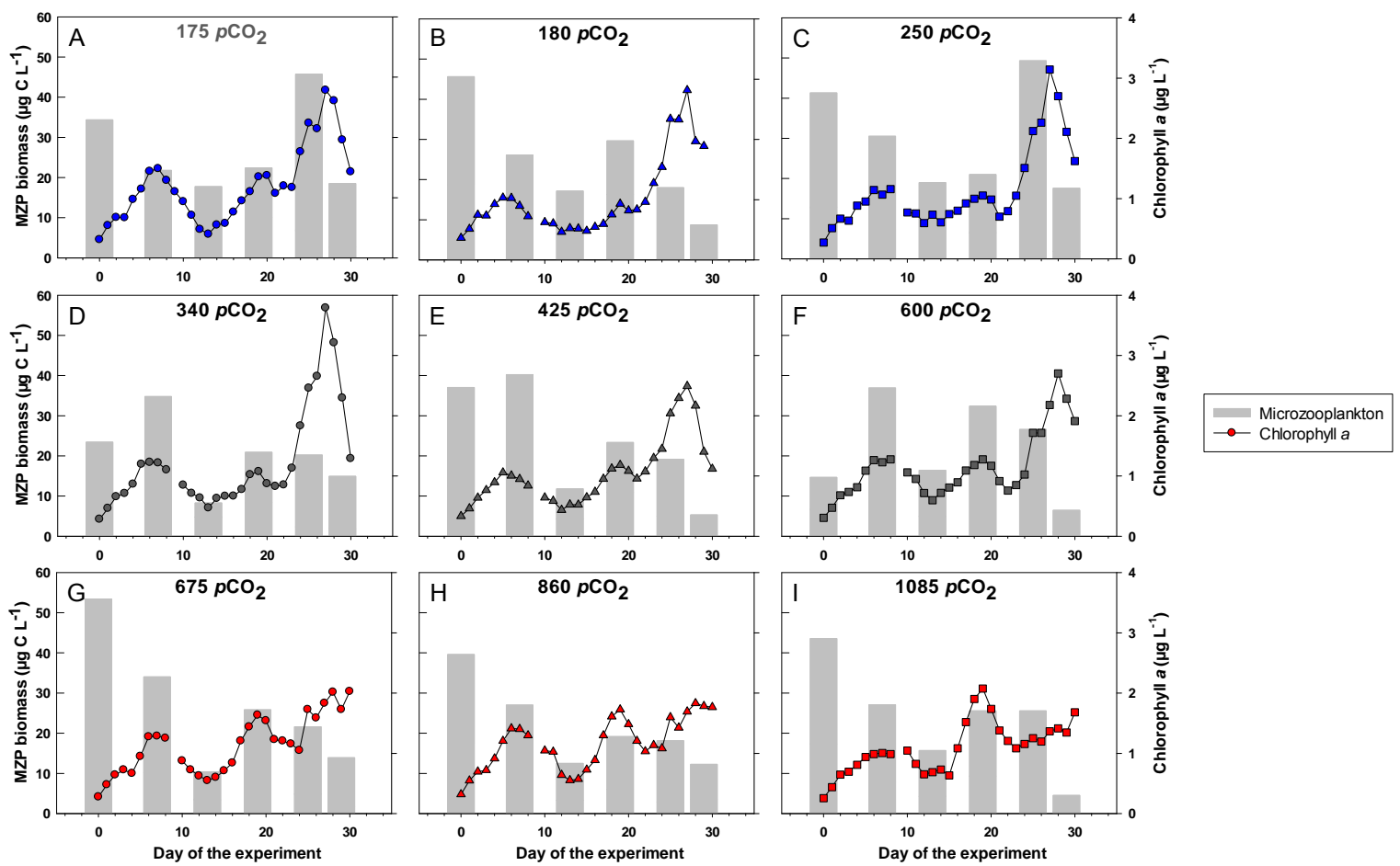

Fig. 1. Microzooplankton (MZP) biomass $\left(\mu \mathrm{C} \mathrm{CL}^{-1}\right)$ and chlorophyll $a$ concentrations $\left(\mu \mathrm{g} \mathrm{CL}^{-1}\right)$ in the different $p \mathrm{CO}_{2}$ treatments (blue lines: $p \mathrm{CO}_{2}$ of 175 (A), 180 (B) and 250 (C); grey lines: $p \mathrm{CO}_{2}$ of 340 (D), 425 (E) and 600 (F); red lines: $p \mathrm{CO} 2$ of 675 (G), 860 (H) and 1085 (I)).

Table 1. Regressions of microzooplankton response variables on $p \mathrm{CO}_{2}$ treatments.

\begin{tabular}{llrrr}
\hline Variable & Unit & Equation & $r^{2}$ & $P$ \\
\hline Biomass maximum Gymnodinium cf. arcticum & $\mu \mathrm{g} \mathrm{C} \mathrm{L}^{-1}$ & $f=5.15+0.0006 \times$ & 0.0096 & 0.8023 \\
Biomass maximum Gyrodinium cf. fusiforme & $\mu \mathrm{g} \mathrm{C} \mathrm{L}^{-1}$ & $f=15.98-0.0114 \times$ & 0.3522 & 0.0921 \\
Biomass maximum Lohmaniella oviformis & $\mu \mathrm{g} \mathrm{C} \mathrm{L}^{-1}$ & $f=0.91+0.001 \times$ & 0.0240 & 0.6907 \\
Biomass maximum Rimostrombidium sp. & $\mu \mathrm{g} \mathrm{C} \mathrm{L}^{-1}$ & $f=1.30+0.0006 \times$ & 0.0217 & 0.7054 \\
Biomass maximum Strombidium cf. conicum & $\mu \mathrm{g} \mathrm{C} \mathrm{L}^{-1}$ & $f=1.95-0.0009 \times$ & 0.2796 & 0.1433 \\
Biomass maximum Katodinium cf. glaucum & $\mu \mathrm{g} \mathrm{C} \mathrm{L}^{-1}$ & $f=2.73-0.0002 \times$ & 0.0153 & 0.7510 \\
Microzooplankton diversity & $\mathrm{H}^{\prime}$ & $f=1.72+7.91 \times 10^{-007} \times$ & $3 \times 10^{-05}$ & 0.9883 \\
Biomass maximum (total MZP) & $\mu \mathrm{g} \mathrm{CL}^{-1}$ & $f=40.22-0.0186 \times$ & 0.1249 & 0.1249 \\
Cumulative biomass (total MZP) & $\mu \mathrm{g} \mathrm{CL}^{-1}$ & $f=154.14-0.0115 \times$ & 0.0418 & 0.5980 \\
Cumulative biomass (ciliates) & $\mu \mathrm{g} \mathrm{CL}^{-1}$ & $f=42.45+0.0091 \times$ & 0.2190 & 0.2040 \\
Cumulative biomass (dinoflagellates) & $\mu \mathrm{g} \mathrm{C} \mathrm{L}^{-1}$ & $f=108.69-0.0205 \times$ & 0.1618 & 0.2831 \\
\hline
\end{tabular}

with glass beads ( 2 and $4 \mathrm{~mm}$ ) in a cell mill thereafter. After centrifugation at $5000 \mathrm{rpm}$, chlorophyll $a$ concentrations were determined in the supernatant on a fluorometer (TURNER, 10-AU) according to Welschmeyer (1994).

\subsection{Statistical analysis}

To test for significant effects of $p \mathrm{CO}_{2}$ on MZP diversity, a regression analysis was conducted. As an independent factor, $p \mathrm{CO}_{2}$ and, as a dependent factor, $H^{\prime}$ were chosen using
STATISTICA 6.0. Diversity was calculated using PRIMER 5.2 (ㄷ 2001 Primer-E Ltd.).

\section{Results}

\subsection{Chlorophyll $a$, phytoplankton biomass and composition}

The phytoplankton standing stock started with fairly low values at the beginning of the experiment showing initial 

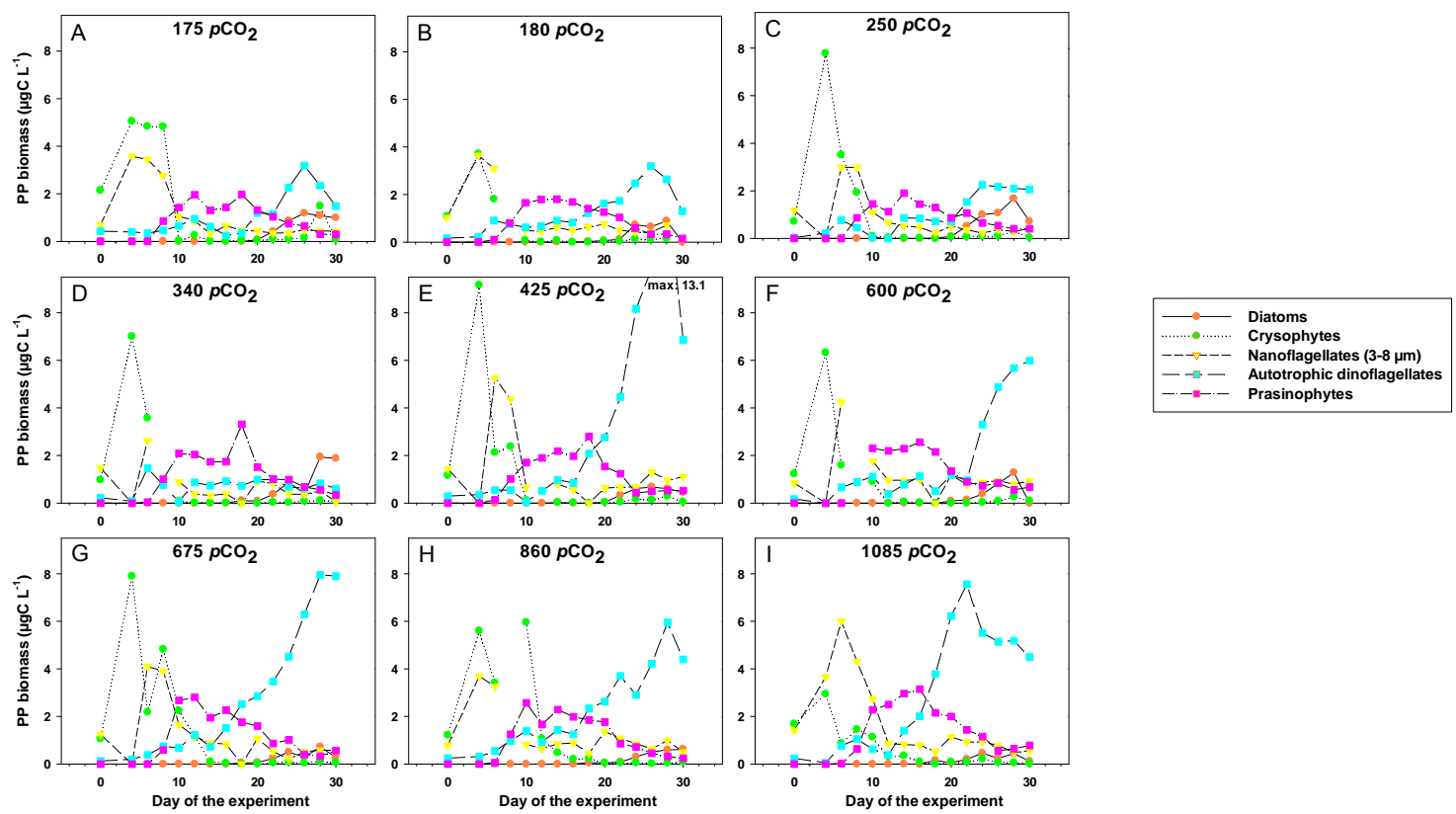

Fig. 2. Phytoplankton (PP) biomass $\left(\mu \mathrm{g} \mathrm{CL}^{-1}\right.$ ) of different taxonomic groups (orange circles: diatoms; green circles: chrysophytes; yellow triangles: flagellates $(3-8 \mu \mathrm{m})$; blue circles: autotrophic dinoflagellates (mainly Heterocapsa rotundata); and pink squares: prasinophytes) in the different $p \mathrm{CO}_{2}$ treatments $\left(p \mathrm{CO}_{2}\right.$ of $175(\mathbf{A}), 180(\mathbf{B}), 250(\mathbf{C}), 340(\mathbf{D}), 425(\mathbf{E}), 600(\mathbf{F}), 675(\mathbf{G}), 860(\mathbf{H})$ and $\left.1085(\mathbf{I})\right)$.

chlorophyll $a$ concentrations between $0.26\left(\mathrm{COO}_{2}\right.$ 1085) and $0.36 \mu \mathrm{g} \mathrm{L}^{-1}\left(\mathrm{COO}_{2} 180\right)$ (Fig. 1). In general, a three-phase bloom development occurred at all $p \mathrm{CO}_{2}$ levels: the first phase before nutrient addition (before day 13), the second phase after nutrient addition until the second chlorophyll minimum (day 13-21) and the third phase until the end of the experiment (after day 21). Each phase was characterized by an increase in phytoplankton biomass and a subsequent decline in chlorophyll $a$ right after the bloom. Chlorophyll $a$ reached maximum peak heights during the third phase of bloom development while highest chlorophyll $a$ concentrations occurred at low $\left(p \mathrm{CO}_{2}: 175-250\right.$; Fig. 1a-c), and intermediate $p \mathrm{CO}_{2}$ levels ( $p \mathrm{CO}_{2}: 340-600$; Fig. 1d-f) and reduced chlorophyll $a$ peaks were observed at high $p \mathrm{CO}_{2}$ levels $\left(p \mathrm{CO}_{2}\right.$ : 675-1085; Fig. 1g-i).

During the first phase of bloom development, the phytoplankton (PP) community was dominated by chrysophytes and nanoflagellates (3-8 $\mu \mathrm{m}$ ) at all $p \mathrm{CO}_{2}$ levels (Fig. 2). During the second phase, a moderate bloom of prasinophytes ( $\sim 5 \mu \mathrm{m}$ ) occurred showing higher peak heights at intermediate and high $p \mathrm{CO}_{2}$ levels $\left(p \mathrm{CO}_{2}: 425-1085\right.$; Fig. $\left.2 \mathrm{~d}-\mathrm{i}\right)$ (see Brussaard et al., 2013 for details). The third phase was dominated by autotrophic dinoflagellates (mainly Heterocapsa rotundata), which showed a higher biomass at intermediate and high $p \mathrm{CO}_{2}$ levels ( $p \mathrm{CO}_{2}$ : 425-1085; Fig. 2e-i). Diatoms were of minor importance occurring only at low biomass at the end of the experiment.

\subsection{Microzooplankton biomass}

The experiment started with fairly high MZP biomass at all $p \mathrm{CO}_{2}$ levels ranging between a minimum of $15 \mu \mathrm{g} \mathrm{L} \mathrm{L}^{-1}\left(p \mathrm{CO}_{2} \quad 600\right)$ and a maximum of $54 \mu \mathrm{C} \mathrm{CL}-1\left(p \mathrm{CO}_{2} 675\right)$ (Fig. 1a-i). While the MZP biomass in the low $\left(p \mathrm{CO}_{2}: 175-250\right.$; Fig. 1a-c) and the high $p \mathrm{CO}_{2}$ levels $\left(p \mathrm{CO}_{2}\right.$ : 675-1085; Fig. 1g-i) decreased during the first phase of the experiment until day 13 , biomass in the intermediate $p \mathrm{CO}_{2}$ level $\left(~ p \mathrm{CO}_{2}: 340-600\right.$; Fig. 1d-f) increased from day 0 to day 7 , followed by a decline until day 13. During the second and the third phase, an increase in MZP biomass was observed at all $p \mathrm{CO}_{2}$ levels reaching highest biomass peaks of $46 \mu \mathrm{g} \mathrm{CL} \mathrm{C}^{-1}\left(p \mathrm{CO}_{2} 175\right.$, Fig. 1a) and $50 \mu \mathrm{gCL}^{-1}\left(\mathrm{CO}_{2} 250\right.$, Fig. 1c) at low $p \mathrm{CO}_{2}$ levels. However, no correlation was found between the MZP biomass maxima and the different $p \mathrm{CO}_{2}$ treatments (Table 1). In addition, no trend was observed for the cumulative biomass (total MZP, ciliates and dinoflagellates) in relation to the different $p \mathrm{CO}_{2}$ treatments (Table 1).

\subsection{Microzooplankton composition and diversity}

Heterotrophic dinoflagellates dominated the MZP community throughout the experiment, independent of $p \mathrm{CO}_{2}$ level, while ciliates contributed to lower proportions to the MZP biomass (Fig. 3a-i). The taxonomic composition of the MZP community showed almost identical patterns at all $p \mathrm{CO}_{2}$ levels. Table 2 shows the taxonomic composition of MZP (biomass in $\mu \mathrm{g} \mathrm{CL}^{-1}$ ) over the course of the mesocosm 
Table 2. Taxonomic composition of microzooplankton (biomass in $\mu \mathrm{g} \mathrm{CL}^{-1}$ ) over the course of the mesocosm experiment (white rows: dinoflagellates; light grey rows: ciliates) in the different $p \mathrm{CO}_{2}$ treatments.

\begin{tabular}{|c|c|c|c|c|c|c|c|c|c|c|c|c|c|c|c|c|c|c|}
\hline \multirow{2}{*}{ Taxa } & \multicolumn{6}{|c|}{$175 p \mathrm{CO}_{2}$ (Day of the experiment) } & \multicolumn{6}{|c|}{$180 p \mathrm{CO}_{2}$ (Day of the experiment) } & \multicolumn{6}{|c|}{$250 p \mathrm{CO}_{2}$ (Day of the experiment) } \\
\hline & 0 & 7 & 13 & 19 & 25 & 29 & 0 & 7 & 13 & 19 & 25 & 29 & 0 & 7 & 13 & 19 & 25 & 29 \\
\hline Gyrodinium cf. fusiforme & 21.50 & 13.52 & 5.99 & 8.45 & 22.81 & 3.95 & 21.12 & 15.13 & 3.92 & 7.45 & 8.52 & 1.34 & 21.27 & 16.20 & 5.15 & 10.90 & 18.28 & 6.45 \\
\hline Protoperidinium $\mathrm{cf}$. brevipes & 3.93 & 4.21 & 1.53 & 2.62 & 5.34 & 3.98 & 4.38 & 3.02 & 2.67 & 3.24 & 2.62 & 1.13 & 6.23 & 4.58 & 1.39 & 1.98 & 6.98 & 1.60 \\
\hline Protoperidinium cf. ovatum & 0.44 & 0.40 & 0.54 & 0.89 & 3.09 & 2.95 & 0.24 & 0.10 & 0.97 & 1.38 & 2.46 & 0.68 & 0.30 & 0.37 & 0.52 & 0.73 & 2.73 & 0.61 \\
\hline Gymnodinium cf. arcticum & 0.62 & 0.62 & 0.00 & 0.00 & 3.10 & 0.31 & 0.31 & 1.24 & 0.93 & 0.93 & 0.31 & 2.17 & 0.31 & 0.00 & 0.00 & 0.00 & 5.58 & 1.71 \\
\hline Katodinium cf. glaucum & 0.18 & 0.00 & 0.09 & 0.00 & 0.35 & 0.18 & 0.00 & 0.22 & 0.00 & 0.35 & 0.44 & 0.66 & 0.09 & 0.09 & 0.09 & 0.00 & 0.44 & 0.20 \\
\hline Protoperidinium cf. pellucidum & 0.75 & 0.86 & 0.43 & 0.43 & 4.28 & 4.38 & 0.86 & 1.28 & 1.92 & 0.00 & 2.57 & 0.86 & 0.32 & 1.92 & 0.21 & 0.86 & 3.42 & 5.13 \\
\hline Strombidium cf. conicum & 0.00 & 0.04 & 1.99 & 0.40 & 0.51 & 0.47 & 0.25 & 0.40 & 1.91 & 0.61 & 0.43 & 0.04 & 0.05 & 0.14 & 2.38 & 0.47 & 0.79 & 0.07 \\
\hline Strombidium capitatum & 0.00 & 0.00 & 6.79 & 5.66 & 2.26 & 0.00 & 6.04 & 1.51 & 1.51 & 10.94 & 0.00 & 0.00 & 7.55 & 1.89 & 6.41 & 1.13 & 4.53 & 0.00 \\
\hline Cyst Strombidium capitatum & 1.65 & 0.47 & 0.24 & 0.47 & 1.88 & 0.71 & 5.65 & 0.24 & 0.24 & 0.00 & 0.24 & 0.71 & 2.24 & 2.12 & 1.41 & 0.00 & 2.35 & 0.24 \\
\hline Strombidium spp. & 1.61 & 0.23 & 0.29 & 0.29 & 0.06 & 0.04 & 1.94 & 0.42 & 0.34 & 0.50 & 0.00 & 0.00 & 1.97 & 0.92 & 0.87 & 0.37 & 0.09 & 0.00 \\
\hline Rimostrombidium sp. & 0.61 & 0.26 & 0.69 & 0.87 & 0.17 & 0.09 & 0.00 & 0.26 & 0.09 & 0.78 & 0.00 & 0.26 & 0.30 & 0.69 & 0.52 & 2.60 & 0.26 & 0.17 \\
\hline Lohmaniella oviformis & 0.20 & 0.10 & 0.01 & 0.77 & 0.60 & 0.00 & 0.14 & 0.16 & 0.57 & 1.25 & 0.00 & 0.01 & 0.02 & 0.09 & 0.05 & 0.58 & 0.15 & 0.34 \\
\hline Myrionecta rubra & 0.72 & 0.36 & 0.36 & 0.00 & 0.00 & 0.00 & 2.29 & 0.36 & 0.00 & 0.00 & 0.00 & 0.24 & 0.30 & 0.96 & 0.24 & 0.00 & 0.00 & 0.00 \\
\hline Strobilidium spiralis & 1.11 & 0.00 & 0.00 & 0.64 & 1.27 & 1.11 & 0.32 & 0.48 & 1.11 & 0.48 & 0.32 & 0.16 & 0.40 & 0.16 & 0.32 & 0.00 & 1.91 & 0.08 \\
\hline Laboea strobila & 1.05 & 0.79 & 0.79 & 1.31 & 0.53 & 0.79 & 2.36 & 1.71 & 2.89 & 2.36 & 0.53 & 0.53 & 0.00 & 0.53 & 1.84 & 1.84 & 2.63 & 1.05 \\
\hline \multirow{2}{*}{ Taxa } & \multicolumn{6}{|c|}{$340 \mathrm{pCO}_{2}$ (Day of the experiment) } & \multicolumn{6}{|c|}{$425 p \mathrm{CO}_{2}$ (Day of the experiment) } & \multicolumn{6}{|c|}{$600 \mathrm{pCO}_{2}$ (Day of the experiment) } \\
\hline & 0 & 7 & 13 & 19 & 25 & 29 & 0 & 7 & 13 & 19 & 25 & 29 & 0 & 7 & 13 & 19 & 25 & 29 \\
\hline Gyrodinium cf. fusiforme & 9.94 & 13.05 & 2.15 & 7.37 & 7.37 & 2.99 & 18.20 & 16.59 & 3.99 & 5.53 & 5.22 & 0.42 & 6.14 & 18.66 & 6.68 & 8.45 & 9.37 & 1.46 \\
\hline Gymnodinium cf. arcticum & 1.61 & 4.87 & 0.54 & 2.62 & 5.05 & 3.02 & 3.78 & 7.02 & 1.73 & 2.99 & 4.68 & 0.73 & 0.83 & 4.77 & 2.40 & 4.03 & 10.09 & 0.66 \\
\hline Katodinium cf. glaucum & 0.25 & 0.65 & 0.25 & 1.20 & 1.96 & 1.86 & 0.62 & 2.02 & 0.65 & 1.15 & 2.71 & 0.56 & 0.03 & 0.78 & 0.80 & 1.77 & 3.37 & 0.34 \\
\hline Protoperidinium cf. pellucidum & 0.16 & 0.00 & 0.00 & 0.93 & 0.62 & 0.93 & 0.31 & 1.86 & 0.31 & 0.62 & 0.00 & 1.55 & 0.62 & 0.00 & 0.93 & 0.00 & 2.48 & 1.40 \\
\hline Protoperidinium cf. brevipes & 0.00 & 0.22 & 0.00 & 0.40 & 0.31 & 0.18 & 0.00 & 0.44 & 0.18 & 0.18 & 0.22 & 0.22 & 0.18 & 0.09 & 0.04 & 0.09 & 0.00 & 0.09 \\
\hline Protoperidinium cf. ovatum & 0.53 & 0.86 & 0.64 & 0.00 & 2.57 & 4.06 & 1.71 & 0.00 & 0.64 & 1.92 & 1.28 & 0.96 & 0.21 & 0.86 & 0.64 & 1.92 & 0.00 & 1.50 \\
\hline Strombidium $\mathrm{cf}$. conicum & 0.00 & 1.05 & 0.43 & 0.29 & 0.25 & 0.33 & 0.18 & 1.30 & 1.59 & 0.65 & 0.43 & 0.22 & 0.00 & 1.26 & 1.23 & 0.54 & 0.22 & 0.00 \\
\hline Strombidium capitatum & 5.28 & 7.92 & 3.02 & 3.02 & 0.00 & 0.38 & 2.64 & 4.53 & 1.13 & 4.90 & 3.77 & 0.00 & 5.09 & 8.30 & 2.26 & 1.13 & 0.00 & 0.00 \\
\hline Cyst Strombidium capitatum & 2.47 & 1.06 & 0.00 & 0.71 & 0.47 & 0.71 & 1.65 & & 0.94 & 0.47 & 0.00 & 0.47 & 1.18 & 0.24 & 0.47 & 0.00 & 0.00 & 0.24 \\
\hline Strombidium spp. & 0.16 & 2.25 & 0.06 & 0.23 & 0.02 & 0.03 & 2.90 & 4.35 & 0.20 & 0.47 & 0.11 & 0.00 & 0.00 & 1.30 & 0.32 & 0.31 & 0.17 & 0.00 \\
\hline Rimostrombidium sp. & 0.22 & 1.13 & 0.35 & 1.47 & 0.09 & 0.09 & 0.00 & 0.69 & 0.43 & 0.43 & 0.09 & 0.00 & 0.13 & 0.43 & 0.35 & 4.60 & 0.00 & 0.13 \\
\hline Lohmaniella oviformis & 0.01 & 0.11 & 0.06 & 0.91 & 0.89 & 0.41 & 0.11 & 0.07 & 0.10 & 1.27 & 0.24 & 0.23 & 0.02 & 0.11 & 0.16 & 1.38 & 0.65 & 0.18 \\
\hline Myrionecta rubra & 1.39 & 1.08 & 0.72 & 0.00 & 0.00 & 0.00 & 2.05 & 0.00 & 0.00 & 0.00 & 0.00 & 0.00 & 0.24 & 0.96 & 0.36 & 6.39 & 0.00 & 0.00 \\
\hline Strobilidium spiralis & 0.64 & 0.80 & 0.00 & 1.27 & 0.64 & 0.00 & 0.16 & 0.32 & 0.96 & 0.00 & 0.32 & 0.16 & 0.00 & 0.16 & 0.48 & 0.48 & 0.48 & 0.08 \\
\hline Laboea strobila & 0.79 & 0.79 & 0.53 & 0.79 & 0.26 & 0.26 & 2.89 & 0.00 & 0.53 & 3.41 & 0.53 & 0.00 & 0.00 & 0.26 & 0.53 & 1.84 & 0.00 & 0.39 \\
\hline \multirow{2}{*}{ Taxa } & \multicolumn{6}{|c|}{$675 p \mathrm{CO}_{2}$ (Day of the experiment) } & \multicolumn{6}{|c|}{$860 p \mathrm{CO}_{2}$ (Day of the experiment) } & \multicolumn{6}{|c|}{$1085 \mathrm{pCO}_{2}$ (Day of the experiment) } \\
\hline & 0 & 7 & 13 & 19 & 25 & 29 & 0 & 7 & 13 & 19 & 25 & 29 & 0 & 7 & 13 & 19 & 25 & 29 \\
\hline Gyrodinium cf. fusiforme & 20.43 & 16.74 & 3.07 & 6.45 & 7.37 & 2.23 & 17.47 & 10.37 & 3.76 & 6.68 & 6.76 & 1.11 & 19.20 & 11.90 & 5.53 & 5.68 & 3.46 & 0.38 \\
\hline Gymnodinium cf. arcticum & 4.70 & 5.61 & 1.46 & 3.36 & 3.24 & 3.61 & 2.55 & 4.28 & 1.61 & 3.29 & 4.81 & 2.81 & 4.38 & 4.01 & 3.14 & 5.74 & 3.14 & 1.39 \\
\hline Katodinium cf. glaucum & 0.44 & 0.40 & 0.80 & 2.63 & 2.70 & 1.51 & 0.30 & 0.62 & 0.75 & 2.53 & 2.11 & 0.90 & 0.46 & 0.84 & 0.59 & 2.35 & 2.15 & 0.70 \\
\hline Protoperidinium cf. pellucidum & 0.31 & 0.00 & 0.31 & 0.00 & 1.55 & 3.41 & 0.16 & 0.00 & 0.00 & 0.31 & 0.93 & 2.17 & 0.31 & 0.31 & 0.00 & 0.00 & 2.17 & 1.40 \\
\hline Protoperidinium cf. brevipes & 0.09 & 0.22 & 0.26 & 0.22 & 0.40 & 0.18 & 0.09 & 0.22 & 0.09 & 0.35 & 0.09 & 0.11 & 0.00 & 0.26 & 0.22 & 0.31 & 0.31 & 0.11 \\
\hline Protoperidinium cf. ovatum & 1.92 & 0.86 & 1.07 & 1.71 & 1.50 & 1.28 & 1.60 & 1.50 & 2.99 & 0.00 & 0.64 & 1.60 & 1.92 & 1.92 & 1.92 & 2.14 & 1.50 & 0.00 \\
\hline Strombidium cf. conicum & 0.47 & 0.43 & 0.76 & 0.72 & 0.00 & 0.00 & 0.13 & 0.25 & 1.16 & 0.14 & 0.25 & 0.18 & 0.33 & 0.61 & 1.55 & 0.40 & 0.40 & 0.13 \\
\hline Strombidium capitatum & 11.32 & 5.28 & 1.51 & 1.51 & 0.00 & 0.38 & 9.62 & 3.40 & 1.13 & 0.00 & 0.00 & 0.19 & 5.66 & 3.02 & 1.51 & 5.66 & 1.13 & 0.00 \\
\hline Cyst Strombidium capitatum & 6.83 & 1.18 & 0.47 & 1.88 & 1.41 & 0.00 & 2.47 & 1.65 & 0.94 & 0.00 & 0.00 & 0.71 & 4.24 & 0.47 & 0.24 & 0.24 & 1.88 & 0.00 \\
\hline Strombidium spp. & 3.23 & 1.42 & 0.07 & 0.06 & 0.00 & 0.00 & 0.42 & 1.21 & 0.06 & 0.03 & 0.01 & 0.00 & 2.46 & 2.51 & 0.23 & 0.19 & 0.29 & 0.01 \\
\hline Rimostrombidium sp. & 0.00 & 0.35 & 0.17 & 1.21 & 0.43 & 0.09 & 0.22 & 0.69 & 0.00 & 0.43 & 0.35 & 0.43 & 0.00 & 0.35 & 0.52 & 0.82 & 2.17 & 0.13 \\
\hline Lohmaniella oviformis & 0.19 & 0.16 & 0.06 & 0.27 & 0.00 & 0.61 & 0.09 & 0.22 & 0.11 & 0.96 & 0.70 & 0.28 & 0.15 & 0.14 & 0.47 & 0.96 & 1.11 & 0.03 \\
\hline Myrionecta rubra & 1.33 & 0.24 & 0.36 & 0.00 & 0.00 & 0.00 & 4.40 & 0.24 & 0.24 & 0.00 & 0.00 & 0.00 & 1.45 & 0.00 & 0.00 & 0.00 & 0.36 & 0.00 \\
\hline Strobilidium spiralis & 0.80 & 0.80 & 0.80 & 2.87 & 1.43 & 0.64 & 0.08 & 0.80 & 0.32 & 2.23 & 1.75 & 0.40 & 0.48 & 0.32 & 0.80 & 0.96 & 4.62 & 0.40 \\
\hline Laboea strobila & 1.84 & 0.79 & 0.00 & 3.68 & 1.58 & 0.00 & 0.13 & 1.84 & 0.53 & 2.36 & 0.00 & 1.58 & 2.89 & 1.05 & 0.53 & 0.53 & 1.31 & 0.00 \\
\hline
\end{tabular}

experiment, while Table A2 shows MZP abundance data (individuals $\left.* \mathrm{~mL}^{-1}\right)$. In general, small-sized $(<30 \mu \mathrm{m})$ ciliates and dinoflagellates played only a minor role while large-sized $(>30 \mu \mathrm{m})$ ciliates and dinoflagellates showed a higher MZP biomass. Small-sized ciliates were comprised of the choreotrichid Lohmaniella oviformis and strombidiids (Strombidium sp.), while small-sized dinoflagellates were comprised of Gymnodinium cf. arcticum, Katodinium cf. glaucum and Protoperidinium brevipes. Large-sized ciliates were mainly represented by Strombidium capitatum and large-sized dinoflagellates by Gyrodinium cf. fusiforme. The dinoflagellate Protoperidinium pellucidum and Protoperidinium ovatum and the ciliates Laboea strobila, Strobilidium spiralis, Strombidium cf. conicum, Rimostrombidium sp. and Myrionecta rubra occurred only sporadically. MZP diversity $\left(H^{\prime}\right)$ ranged between $1.64\left(p \mathrm{CO}_{2} 175\right)$ and $1.79\left(p \mathrm{CO}_{2} 340\right)$, and no correlation was found between $\mathrm{H}^{\prime}$ and the different $p \mathrm{CO}_{2}$ treatments (Table 1).

\subsection{Microzooplankton succession}

During the first phase of bloom development, biomass response of MZP at the different $p \mathrm{CO}_{2}$ levels was quite heterogeneous. The strongest positive biomass response to increasing chlorophyll $a$ concentrations during the first phase was observed for the dinoflagellate Gymnodinium cf. arcticum 

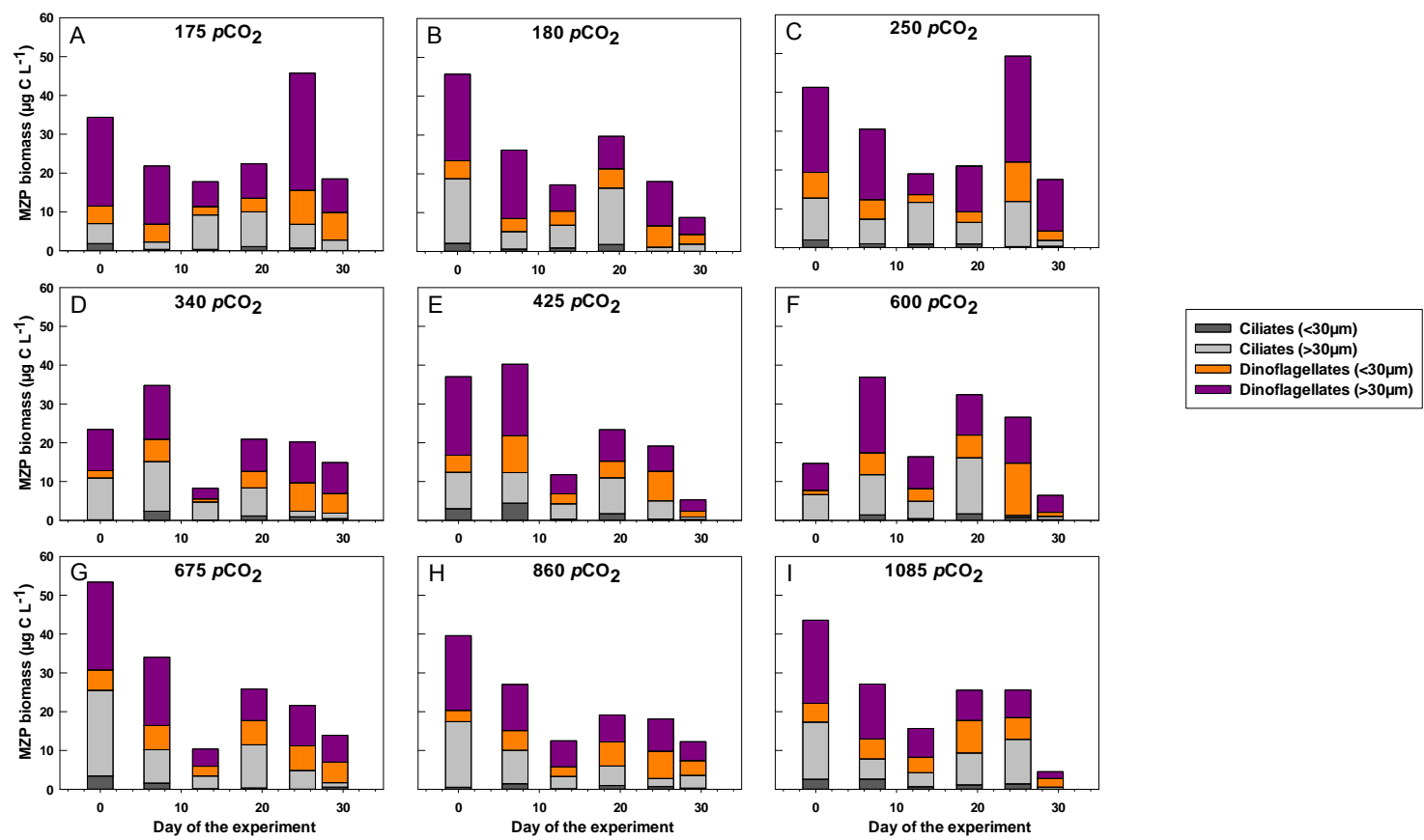

Fig. 3. Microzooplankton (MZP) biomass $\left(\mu \mathrm{g} \mathrm{CL}^{-1}\right.$ ) (dark grey: ciliates $<30 \mu \mathrm{m}$; light grey: ciliates $>30 \mu \mathrm{m}$; orange: dinoflagellates $<30 \mu \mathrm{m}$; purple: dinoflagellates $>30 \mu \mathrm{m})$ in the different $p \mathrm{CO}_{2}$ treatments $\left(p \mathrm{CO}_{2}\right.$ of $175(\mathbf{A}), 180(\mathbf{B}), 250(\mathbf{C}), 340(\mathbf{D}), 425(\mathbf{E}), 600(\mathbf{F})$, $675(\mathbf{G}), 860(\mathbf{H})$ and 1085 (I)).

(Fig. 4a). Most MZP species showed a distinct biomass increase during the second or the third phase of bloom development at all $p \mathrm{CO}_{2}$ levels (Fig. 4). While the biomass of the ciliates Lohmaniella oviformis, Rimostrombidium sp. and Strombidium cf. conicum peaked already during the second phase of bloom development at all $p \mathrm{CO}_{2}$ levels (Fig. 4ce), others, e.g. Katodinium cf. glaucum, showed increasing biomass until the third phase. Overall responses of single species to increasing phytoplankton availability showed similar patterns at all $p \mathrm{CO}_{2}$ levels, and no trend in biomass maxima of specific MZP species in relation to the different $p \mathrm{CO}_{2}$ levels was observed (Table 1).

\section{Discussion}

The initial MZP biomass of $15-54 \mu \mathrm{g} \mathrm{C} \mathrm{L}{ }^{-1}$ in our mesocosm study in Kongsfjorden in late May 2012 was high compared to studies from the same season and location where MZP biomass ranged between 2 and $13 \mu \mathrm{g} \mathrm{L}^{-1}$ (Seuthe et al., 2011; Hodal et al., 2012). However, our data are in line with post-bloom MZP biomass reported for other coastal Arctic regions, e.g. Disko Bay, West Greenland (Levinsen et al., 2000; Hansen et al., 2003). In good agreement to Hodal et al. (2012), small-sized ciliates and dinoflagellates were of minor importance while large-sized ciliates and dinoflagellates dominated the MZP. Furthermore, the taxonomic composition of the MZP community we found in 2012 was simi- lar to that of the post-bloom period in Kongsfjorden in 2006 (Seuthe et al., 2011).

\subsection{Direct effects of high $p \mathrm{CO}_{2}$ will alter microzooplankton community composition and diversity}

Previous studies on the impact of OA on MZP communities showed no clear trend (Suffrian et al., 2008; Rose et al., 2009). In order to understand the causes and consequences of future $\mathrm{CO}_{2}$ and $\mathrm{pH}$ conditions, it is essential to consider all components of the plankton, from protists to metazoans, and to compare among sites with different degrees of natural pH fluctuations (Nielsen et al., 2012).

MZP play a major role in the global carbon cycle by fixing inorganic carbon, and the interplay between auto- and heterotrophic protists is crucial since up to $60-75 \%$ of phytoplankton production in coastal and open oceans is consumed by MZP (Landry and Calbet, 2004). MZP thus act as a trophic link between phytoplankton and mesozooplankton and contribute substantially to the cycling of bulk organic matter and nutrients (Irigoien et al., 2005; Calbet and Saiz 2005). However, only few studies have addressed the impact of OA on MZP communities so far, although there is indication for $\mathrm{pH}$ sensitivity of MZP especially at elevated $\mathrm{pH}$ ( $\mathrm{pH}$ of $\sim 8.0$ to 9.5) (Hinga, 1992; Pedersen and Hansen, 2003). Experimental studies off the coast of Norway (Suffrian et al., 2008) and in the open North Atlantic Ocean (Rose 

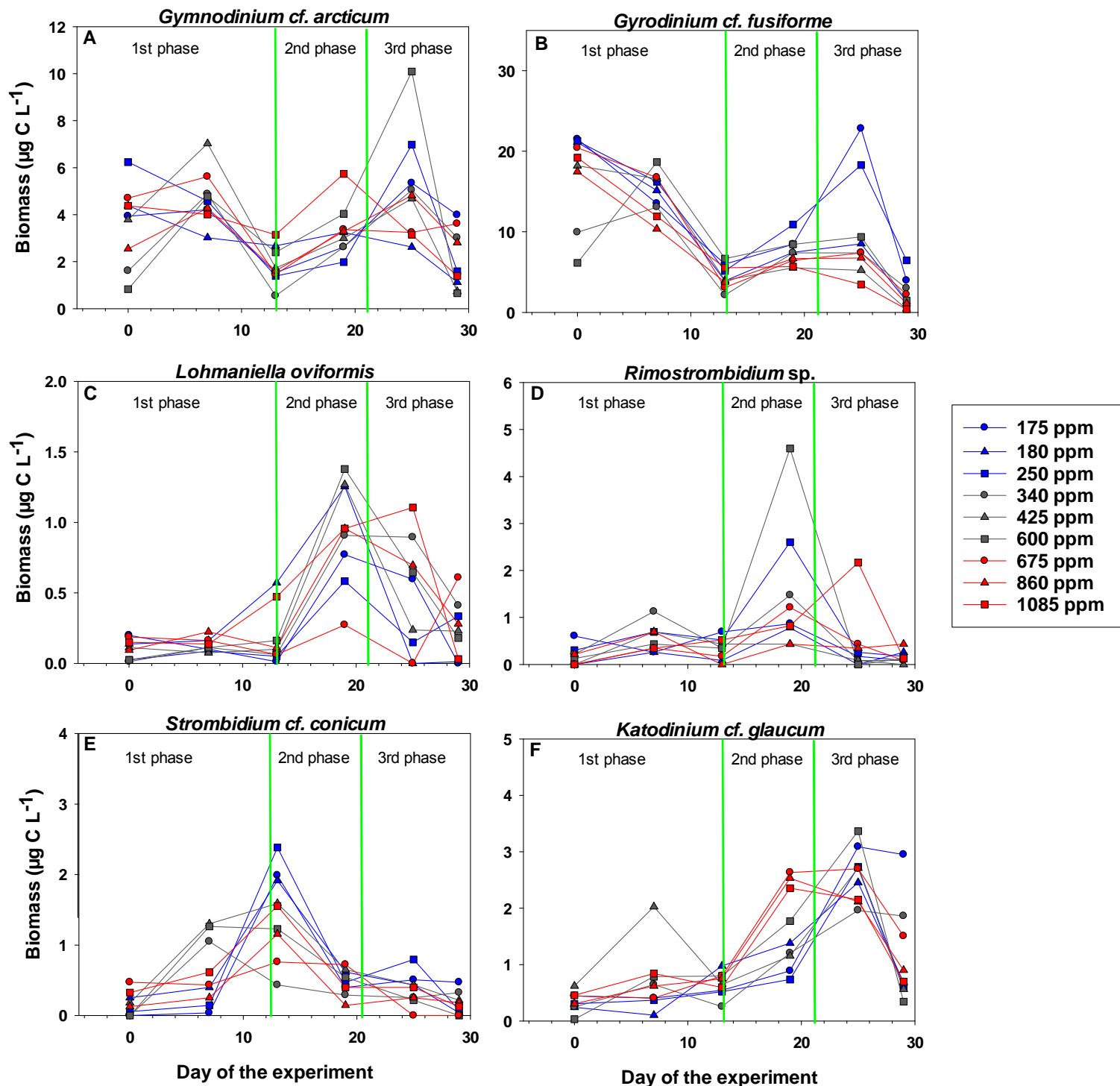

Fig. 4. Temporal succession of specific microzooplankton species: Gymnodinium cf. arcticum (A), Gyrodinium cf. fusiforme (B), Lohmaniella oviformis (C), Rimostrombidium sp. (D), Strombidium cf. conicum (E) and Katodinium cf. glaucum (F) in the different $p \mathrm{CO}_{2}$ treatments (blue lines: $p \mathrm{CO}_{2}$ of 175, 180 and 250; grey lines: $p \mathrm{CO}_{2}$ of 340, 425 and 600; red lines: $p \mathrm{CO}_{2}$ of 675, 860 and 1085). Note the different scaling on the y-axes. Vertical green lines depict the three phases of bloom development.

et al., 2009) found no direct effects of a high $p \mathrm{CO}_{2} /$ low $\mathrm{pH}$ on MZP. This is in line with our observation, since no direct effects on MZP composition and diversity was observed; neither the relative shares of ciliates and heterotrophic dinoflagellates were affected nor did a low $\mathrm{pH}$ induce changes in taxonomic composition. However, Nielsen et al. (2012) showed that a reduced $\mathrm{pH}(\sim 6.3)$ can alter the performance of autotrophs (reduced abundance and photosynthetic rate) and MZP (reduced abundance). For coccolithophores such direct effects are assumed to be related to changes in the intra-cellular $\mathrm{pH}$, which in turn alters enzymatic reactions and growth rates (Nimer et al., 1994; Suffrian et al., 2011).
In our study, the changes in $p \mathrm{CO}_{2}$ and $\mathrm{pH}$ were within the range expected for the 21 st century and thus not as extreme as in the scenario simulated by Nielsen et al. (2012). But similar to their study, we found a high tolerance of MZP towards moderate changes in $\mathrm{pH}$. In general, open ocean plankton communities are considered more vulnerable to OA since the $\mathrm{pH}$ in coastal environments fluctuates more strongly with frequent variations by up to 1 or more $\mathrm{pH}$ units (Hansen, 2002; Hinga, 2002). So, even today coastal MZP temporarily experience high $p \mathrm{CO}_{2} / \mathrm{low} \mathrm{pH}$ as predicted for the next century, but the question remains whether communities that are 
Table A1. Exact $\mathrm{pH}$ and $p \mathrm{CO}_{2}$ values in the different $p \mathrm{CO}_{2}$ treatments.

\begin{tabular}{|c|c|c|c|c|c|c|c|c|c|c|c|c|c|c|c|c|c|c|}
\hline \multirow{3}{*}{ 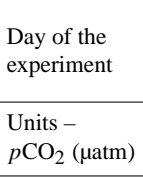 } & \multicolumn{18}{|c|}{$p \mathrm{CO}_{2}$ treatments } \\
\hline & \multicolumn{2}{|c|}{$175 p \mathrm{CO}_{2}$} & \multicolumn{2}{|c|}{$180 p \mathrm{CO}_{2}$} & \multicolumn{2}{|c|}{$250 p \mathrm{CO}_{2}$} & \multicolumn{2}{|c|}{$340 p \mathrm{CO}_{2}$} & \multicolumn{2}{|c|}{$425 p \mathrm{CO}_{2}$} & \multicolumn{2}{|c|}{$600 p \mathrm{CO}_{2}$} & \multicolumn{2}{|c|}{$675 p \mathrm{CO}_{2}$} & \multicolumn{2}{|c|}{$860 p \mathrm{CO}_{2}$} & \multicolumn{2}{|c|}{$1085 p \mathrm{CO}_{2}$} \\
\hline & $\mathrm{pH}$ & $p \mathrm{CO}_{2}$ & $\mathrm{pH}$ & $p \mathrm{CO}_{2}$ & $\mathrm{pH}$ & $p \mathrm{CO}_{2}$ & $\mathrm{pH}$ & $p \mathrm{CO}_{2}$ & $\mathrm{pH}$ & $p \mathrm{CO}_{2}$ & $\mathrm{pH}$ & $p \mathrm{CO}_{2}$ & $\mathrm{pH}$ & $p \mathrm{CO}_{2}$ & $\mathrm{pH}$ & $p \mathrm{CO}_{2}$ & $\mathrm{pH}$ & $p \mathrm{CO}_{2}$ \\
\hline 0 & 8.33 & 181.49 & 8.33 & 180.75 & 8.18 & 247.49 & 8.21 & 249.52 & 8.22 & 244.92 & 7.97 & 240.13 & 8.22 & 242.05 & 8.22 & 242.06 & 8.22 & 241.75 \\
\hline 1 & 8.33 & 179.80 & 8.32 & 180.70 & 8.18 & 246.16 & 8.07 & 357.46 & 7.99 & 438.08 & 7.70 & 424.50 & 7.98 & 445.77 & 7.99 & 435.93 & 7.99 & 438.13 \\
\hline 2 & 8.35 & 170.82 & 8.36 & 167.73 & 8.22 & 239.21 & 8.11 & 322.55 & 7.95 & 489.78 & 7.79 & 783.53 & 7.76 & 770.74 & 7.70 & 906.07 & 7.71 & 869.87 \\
\hline 3 & 8.35 & 168.25 & 8.30 & 169.72 & 8.20 & 249.71 & 8.08 & 350.58 & 7.96 & 470.59 & 7.83 & 595.10 & 7.67 & 967.61 & 7.59 & 1175.17 & 7.48 & 1528.83 \\
\hline 4 & 8.34 & 176.77 & 8.31 & 178.12 & 8.26 & 260.67 & 8.05 & 373.45 & 7.96 & 472.31 & 7.81 & 681.16 & 7.67 & 974.11 & 7.60 & 1144.82 & 7.50 & 1451.02 \\
\hline 5 & 8.33 & 179.35 & 8.32 & 184.76 & 8.36 & 265.45 & 8.06 & 367.27 & 7.90 & 551.82 & 7.84 & 717.55 & 7.68 & 950.37 & 7.57 & 1228.30 & 7.40 & 1833.17 \\
\hline 6 & 8.33 & 177.34 & 8.32 & 164.70 & 8.22 & 263.88 & 8.11 & 324.86 & 8.01 & 418.11 & 7.81 & 699.73 & 7.75 & 801.14 & 7.67 & 980.35 & 7.52 & 1395.01 \\
\hline 7 & 8.32 & 182.19 & 8.32 & 192.15 & 8.28 & 273.02 & 8.05 & 378.86 & 7.93 & 511.71 & 7.86 & 685.76 & 7.70 & 902.34 & 7.60 & 1159.64 & 7.52 & 1396.04 \\
\hline 8 & 8.32 & 184.72 & 8.31 & 187.73 & 8.28 & 270.90 & 8.05 & 375.23 & 7.95 & 486.37 & 7.89 & 689.13 & 7.74 & 829.45 & 7.63 & 1065.26 & 7.51 & 1447.05 \\
\hline 9 & 8.33 & 180.14 & 8.32 & 183.01 & 8.25 & 266.06 & 8.06 & 367.70 & 7.97 & 461.70 & 7.87 & 663.63 & 7.75 & 793.65 & 7.65 & 1012.50 & 7.53 & 1367.89 \\
\hline 10 & 8.32 & 182.96 & 8.32 & 185.66 & 8.22 & 272.00 & 8.05 & 375.18 & 7.98 & 455.18 & 7.86 & 665.56 & 7.76 & 788.59 & 7.66 & 999.31 & 7.54 & 1335.93 \\
\hline 11 & 8.32 & 185.84 & 8.34 & 185.51 & 8.24 & 272.64 & 8.05 & 373.82 & 7.97 & 460.07 & 7.88 & 658.16 & 7.76 & 776.80 & 7.66 & 997.14 & 7.54 & 1338.29 \\
\hline 12 & 8.32 & 182.53 & 8.33 & 187.60 & 8.25 & 268.40 & 8.06 & 369.11 & 7.97 & 461.99 & 7.89 & 660.05 & 7.78 & 742.65 & 7.67 & 965.93 & 7.56 & 1261.48 \\
\hline 13 & 8.32 & 183.12 & 8.33 & 186.02 & 8.28 & 260.85 & 8.06 & 364.83 & 7.97 & 457.47 & 7.90 & 634.51 & 7.77 & 760.95 & 7.68 & 957.02 & 7.56 & 1270.86 \\
\hline 14 & 8.32 & 182.10 & 8.32 & 183.73 & 8.25 & 266.76 & 8.06 & 369.95 & 7.99 & 443.61 & 7.90 & 638.10 & 7.79 & 729.01 & 7.69 & 936.08 & 7.59 & 1182.97 \\
\hline 15 & 8.34 & 175.19 & 8.33 & 176.41 & 8.25 & 254.27 & 8.08 & 348.30 & 8.00 & 428.98 & 7.92 & 610.39 & 7.81 & 692.23 & 7.70 & 901.35 & 7.60 & 1132.42 \\
\hline 16 & 8.34 & 175.61 & 8.33 & 178.60 & 8.23 & 252.83 & 8.08 & 346.25 & 8.01 & 422.53 & 7.91 & 592.21 & 7.82 & 677.54 & 7.72 & 858.68 & 7.63 & 1057.06 \\
\hline 17 & 8.33 & 177.30 & 8.35 & 179.08 & 8.27 & 254.77 & 8.09 & 344.49 & 8.00 & 430.64 & 7.94 & 594.62 & 7.81 & 680.56 & 7.73 & 845.42 & 7.62 & 1097.41 \\
\hline 18 & 8.33 & 180.05 & 8.33 & 185.92 & 8.30 & 258.37 & 8.09 & 344.37 & 8.01 & 422.06 & 7.97 & 594.85 & 7.83 & 658.67 & 7.74 & 820.05 & 7.66 & 1001.83 \\
\hline 19 & 8.33 & 181.87 & 8.33 & 182.09 & 8.28 & 255.98 & 8.08 & 347.22 & 8.01 & 423.26 & 7.97 & 596.51 & 7.83 & 662.84 & 7.74 & 825.54 & 7.66 & 999.54 \\
\hline 20 & 8.35 & 171.86 & 8.35 & 178.21 & 8.34 & 244.22 & 8.10 & 332.62 & 8.01 & 416.03 & 7.99 & 563.49 & 7.84 & 643.15 & 7.76 & 779.18 & 7.69 & 932.96 \\
\hline 21 & 8.35 & 168.41 & 8.36 & 169.97 & 8.28 & 240.94 & 8.11 & 322.58 & 8.04 & 388.48 & 8.01 & 546.61 & 7.87 & 589.47 & 7.77 & 756.50 & 7.71 & 889.40 \\
\hline 22 & 8.35 & 172.59 & 8.36 & 178.70 & & 242.68 & 8.11 & 326.43 & 8.03 & 404.85 & & 554.27 & 7.87 & 604.92 & 7.77 & 760.12 & 7.69 & 934.84 \\
\hline 23 & 8.32 & 184.55 & 8.37 & 180.92 & 8.31 & 253.72 & 8.11 & 330.42 & 7.98 & 455.45 & 8.02 & 578.25 & 7.87 & 609.67 & 7.75 & 802.62 & 7.69 & 935.45 \\
\hline 24 & 8.35 & 169.28 & 8.33 & 172.06 & 8.32 & 234.78 & 8.12 & 316.25 & 8.05 & 385.67 & 8.03 & 545.90 & 7.88 & 585.20 & 7.78 & 760.11 & 7.71 & 897.84 \\
\hline 25 & 8.36 & 166.96 & 8.32 & 165.70 & 8.35 & 227.41 & 8.14 & 301.09 & 8.06 & 368.27 & 8.06 & 516.93 & 7.90 & 562.75 & 7.79 & 731.47 & 7.72 & 865.66 \\
\hline 26 & 8.36 & 164.91 & 8.36 & 164.02 & 8.38 & 221.26 & 8.15 & 296.60 & 8.06 & 367.66 & 8.09 & 500.14 & 7.90 & 562.45 & 7.80 & 719.33 & 7.72 & 871.03 \\
\hline 27 & 8.37 & 162.15 & 8.30 & 160.74 & 8.42 & 221.11 & 8.16 & 286.40 & 8.07 & 362.88 & 8.13 & 493.27 & 7.91 & 546.76 & 7.80 & 708.69 & 7.73 & 843.64 \\
\hline
\end{tabular}

permanently subject to a high $\mathrm{CO}_{2}$ world will display the same level of $\mathrm{pH}$ tolerance.

\subsection{Indirect effects of high $p \mathrm{CO}_{2}$ by changes in food availability and phytoplankton composition will alter the carrying capacity and phenology of MZP}

Elevated $p \mathrm{CO}_{2}$ is known to affect autotrophic processes directly (Riebesell and Tortell, 2011), while MZP are considered to be predominantly indirectly affected by high $p \mathrm{CO} 2$ from changes, e.g. in food availability, phytoplankton community and size structure (Suffrian et al., 2008; Rose et al., 2009).

Our initial expectation was that the different $p \mathrm{CO}_{2}$ levels would induce general shifts in phytoplankton composition, which in turn could affect the carrying capacity and phenology of MZP. Chlorophyll $a$ concentrations in the mesocosms did not show a pronounced response to $\mathrm{CO}_{2}$ enrichment, but an increase with time in all mesocosms, which was not reflected in MZP biomass. Phytoplankton composition in our mesocosms showed some clear $\mathrm{CO}_{2}$-dependent trends, e.g. a positive $\mathrm{CO}_{2}$ effect on dinoflagellates, while prasinophytes and haptophytes profited at low $\mathrm{CO}_{2}$ levels during phase 3 of the experiment (Schulz et al., 2013; Brussaard et al., 2013). However, these changes in phytoplankton community composition altered neither the carrying capacity nor the phenol- ogy of MZP. This might be related to the fact that changes in community composition happened only on short time scales and responses were usually not maintained over a longer period of bloom development (Brussaard et al., 2013). Phytoplankton usually comprise a multitude of species, and thus short-term, $p \mathrm{CO}_{2}$-induced alterations in algal diets of consumers can often be mitigated (Urabe and Waki, 2009). Further, as pointed out by Suffrian et al. (2008), the distinct effects of elevated $\mathrm{CO}_{2}$ on single plankton species observed in laboratory studies are not comparable to those obtained in experiments simulating close-to natural conditions since such complex systems seem to have a higher buffering capacity to changes in $p \mathrm{CO}_{2}$. This is in line with observations of Rose et al. (2009) where no relationship between the MZP community composition and elevated $\mathrm{CO}_{2}$ could be observed.

In the mesocosms, nanophytoplankton (e.g. nanoflagellates and chrysophytes) played a major role during the first phase of bloom development and, apart from MZP grazing, viral lysis enforced the nanophytoplankton bloom to decline (Brussaard et al., 2013). The rapid decline in nanophytoplankton induced by viruses corresponds well with the steep biomass decline of ciliates and dinoflagellates during the first phase of bloom development, which points to a food shortage of MZP. This is also confirmed by the moderate grazing rates observed for MZP during the nanophytoplankton bloom at all $p \mathrm{CO}_{2}$ levels (Brussaard et al., 2013). 
Table A2. Taxonomic composition of microzooplankton (abundance in individuals $\mathrm{mL}^{-1}$ ) over the course of the mesocosm experiment (white rows: dinoflagellates; light grey rows: ciliates) in the different $p \mathrm{CO}_{2}$ treatments.

\begin{tabular}{|c|c|c|c|c|c|c|c|c|c|c|c|c|c|c|c|c|c|c|}
\hline \multirow{2}{*}{ Taxa } & \multicolumn{6}{|c|}{$175 p \mathrm{CO}_{2}$ (Day of the experiment) } & \multicolumn{6}{|c|}{$180 p \mathrm{CO}_{2}$ (Day of the experiment) } & \multicolumn{6}{|c|}{$250 p \mathrm{CO}_{2}$ (Day of the experiment) } \\
\hline & 0 & 7 & 13 & 19 & 25 & 29 & 0 & 7 & 13 & 19 & 25 & 29 & 0 & 7 & 13 & 19 & 25 & 29 \\
\hline Gyrodinium cf. fusiforme & 5.60 & 3.52 & 1.56 & 2.20 & 5.94 & 1.03 & 5.50 & 3.94 & 1.02 & 1.94 & 2.22 & 0.35 & 5.54 & 4.22 & 1.34 & 2.84 & 4.76 & 1.68 \\
\hline Gymnodinium cf. arcticum & 3.18 & 3.40 & 1.24 & 2.12 & 4.32 & 3.22 & 3.54 & 2.44 & 2.16 & 2.62 & 2.12 & 0.91 & 5.04 & 3.70 & 1.12 & 1.60 & 5.64 & 1.29 \\
\hline Katodinium cf. glaucum & 0.70 & 0.64 & 0.86 & 1.40 & 4.88 & 4.66 & 0.38 & 0.16 & 1.54 & 2.18 & 3.88 & 1.08 & 0.48 & 0.58 & 0.82 & 1.16 & 4.32 & 0.96 \\
\hline Protoperidinium cf. pellucidum & 0.04 & 0.04 & 0.00 & 0.00 & 0.20 & 0.02 & 0.02 & 0.08 & 0.06 & 0.06 & 0.02 & 0.14 & 0.02 & 0.00 & 0.00 & 0.00 & 0.36 & 0.11 \\
\hline Protoperidinium cf. brevipes & 0.08 & 0.00 & 0.04 & 0.00 & 0.16 & 0.08 & 0.00 & 0.10 & 0.00 & 0.16 & 0.20 & 0.30 & 0.04 & 0.04 & 0.04 & 0.00 & 0.20 & 0.09 \\
\hline Protoperidinium cf. ovatum & 0.07 & 0.08 & 0.04 & 0.04 & 0.40 & 0.41 & 0.08 & 0.12 & 0.18 & 0.00 & 0.24 & 0.08 & 0.03 & 0.18 & 0.02 & 0.08 & 0.32 & 0.48 \\
\hline Strombidium cf. conicum & 0.00 & 0.02 & 1.10 & 0.22 & 0.28 & 0.26 & 0.14 & 0.22 & 1.06 & 0.34 & 0.24 & 0.02 & 0.03 & 0.08 & 1.32 & 0.26 & 0.44 & 0.04 \\
\hline Strombidium capitatum & 0.00 & 0.00 & 0.36 & 0.30 & 0.12 & 0.00 & 0.32 & 0.08 & 0.08 & 0.58 & 0.00 & 0.00 & 0.40 & 0.10 & 0.34 & 0.06 & 0.24 & 0.00 \\
\hline CystStrombidium capitatum & 0.14 & 0.04 & 0.02 & 0.04 & 0.16 & 0.06 & 0.48 & 0.02 & 0.02 & 0.00 & 0.02 & 0.06 & 0.19 & 0.18 & 0.12 & 0.00 & 0.20 & 0.02 \\
\hline Strombidium spp. & 3.40 & 0.48 & 0.62 & 0.62 & 0.12 & 0.08 & 4.10 & 0.88 & 0.72 & 1.06 & 0.00 & 0.00 & 4.18 & 1.94 & 1.84 & 0.78 & 0.20 & 0.01 \\
\hline Rimostrombidium sp. & 0.14 & 0.06 & 0.16 & 0.20 & 0.04 & 0.02 & 0.00 & 0.06 & 0.02 & 0.18 & 0.00 & 0.06 & 0.07 & 0.16 & 0.12 & 0.60 & 0.06 & 0.04 \\
\hline Lohmaniella oviformis & 0.32 & 0.16 & 0.02 & 1.24 & 0.96 & 0.00 & 0.22 & 0.26 & 0.92 & 2.02 & 0.00 & 0.02 & 0.04 & 0.14 & 0.08 & 0.94 & 0.24 & 0.54 \\
\hline Myrionecta rubra & 0.12 & 0.06 & 0.06 & 0.00 & 0.00 & 0.00 & 0.38 & 0.06 & 0.00 & 0.00 & 0.00 & 0.04 & 0.05 & 0.16 & 0.04 & 0.00 & 0.00 & 0.00 \\
\hline Strobilidium spiralis & 0.14 & 0.00 & 0.00 & 0.08 & 0.16 & 0.14 & 0.04 & 0.06 & 0.14 & 0.06 & 0.04 & 0.02 & 0.05 & 0.02 & 0.04 & 0.00 & 0.24 & 0.01 \\
\hline Laboea strobila & 0.08 & 0.06 & 0.06 & 0.10 & 0.04 & 0.06 & 0.18 & 0.13 & 0.22 & 0.18 & 0.04 & 0.04 & 0.00 & 0.04 & 0.14 & 0.14 & 0.20 & 0.08 \\
\hline \multirow{2}{*}{ Taxa } & \multicolumn{6}{|c|}{$340 p \mathrm{CO}_{2}$ (Day of the experiment) } & \multicolumn{6}{|c|}{$425 p \mathrm{CO}_{2}$ (Day of the experiment) } & \multicolumn{6}{|c|}{$600 \mathrm{pCO}_{2}$ (Day of the experiment) } \\
\hline & 0 & 7 & 13 & 19 & 25 & 29 & 0 & 7 & 13 & 19 & 25 & 29 & 0 & 7 & 13 & 19 & 25 & 29 \\
\hline & 2.59 & 3.40 & & & 1.92 & 0.78 & 4.74 & 4.32 & 1.04 & 1.44 & 1.36 & 0.11 & 1.60 & & 1.74 & 2.20 & 2.44 & 0.38 \\
\hline Gymnodinium cf. arcticum & 1.30 & 3.94 & 0.44 & 2.12 & 4.08 & 2.44 & 3.06 & 5.68 & 1.40 & 2.42 & 3.78 & 0.59 & 0.67 & 3.86 & 1.94 & 3.26 & 8.16 & 0.53 \\
\hline Katodinium cf. glaucum & 0.39 & 1.02 & 0.40 & 1.90 & 3.10 & 2.94 & 0.98 & 3.20 & 1.02 & 1.82 & 4.28 & 0.89 & 0.05 & 1.24 & 1.26 & 2.80 & 5.32 & 0.54 \\
\hline Protoperidinium cf. pellucidum & 0.01 & 0.00 & 0.00 & 0.06 & 0.04 & 0.06 & 0.02 & 0.12 & 0.02 & 0.04 & 0.00 & 0.10 & 0.04 & 0.00 & 0.06 & 0.00 & 0.16 & 0.09 \\
\hline Protoperidinium cf. brevipes & 0.00 & 0.10 & 0.00 & 0.18 & 0.14 & 0.08 & 0.00 & 0.20 & 0.08 & 0.08 & 0.10 & 0.10 & 0.08 & 0.04 & 0.02 & 0.04 & 0.00 & 0.04 \\
\hline Protoperidinium cf. ovatum & 0.05 & 0.08 & 0.06 & 0.00 & 0.24 & 0.38 & 0.16 & 0.00 & 0.06 & 0.18 & 0.12 & 0.09 & 0.02 & 0.08 & 0.06 & 0.18 & 0.00 & 0.14 \\
\hline Strombidium cf. conicum & 0.00 & 0.58 & 0.24 & 0.16 & 0.14 & 0.18 & 0.10 & 0.72 & 0.88 & 0.36 & 0.24 & 0.12 & 0.00 & 0.70 & 0.68 & 0.30 & 0.12 & 0.00 \\
\hline Strombidium & 0.28 & 0.42 & 0.16 & 0.16 & 0.00 & 0.02 & 0.14 & 0.24 & 0.06 & 0.26 & 0.20 & 0.00 & 0.27 & 0.44 & 0.12 & 0.06 & 0.00 & 0.00 \\
\hline Cyst Strombidium capitatum & 0.21 & 0.09 & 0.00 & 0.06 & 0.04 & 0.06 & 0.14 & 0.20 & 0.08 & 0.04 & 0.00 & 0.04 & 0.10 & 0.02 & 0.04 & 0.00 & 0.00 & 0.02 \\
\hline Strombidium spp. & 0.33 & 4.76 & 0.12 & 0.48 & 0.04 & 0.06 & 6.14 & 9.20 & 0.42 & 1.00 & 0.24 & 0.00 & 0.00 & 2.76 & 0.68 & 0.66 & 0.36 & 0.00 \\
\hline Rimostrombidium sp. & 0.05 & 0.26 & 0.08 & 0.34 & 0.02 & 0.02 & 0.00 & 0.16 & 0.10 & 0.10 & 0.02 & 0.00 & 0.03 & 0.10 & 0.08 & 1.06 & 0.00 & 0.03 \\
\hline Lohmaniella oviformis & 0.02 & 0.18 & 0.10 & 1.46 & 1.44 & 0.66 & 0.18 & 0.12 & 0.16 & 2.04 & 0.38 & 0.37 & 0.04 & 0.18 & 0.26 & 2.22 & 1.04 & 0.29 \\
\hline Myrionecta rubra & 0.23 & 0.18 & 0.12 & 0.00 & 0.00 & 0.00 & 0.34 & 0.00 & 0.00 & 0.00 & 0.00 & 0.00 & 0.04 & 0.16 & 0.06 & 1.06 & 0.00 & 0.00 \\
\hline Strobilidium spiralis & 0.08 & 0.10 & 0.00 & 0.16 & 0.08 & 0.00 & 0.02 & 0.04 & 0.12 & 0.00 & 0.04 & 0.02 & 0.00 & 0.02 & 0.06 & 0.06 & 0.06 & 0.01 \\
\hline Laboea strobila & 0.06 & 0.06 & 0.04 & 0.06 & 0.02 & 0.02 & 0.22 & 0.00 & 0.04 & 0.26 & 0.04 & 0.00 & 0.00 & 0.02 & 0.04 & 0.14 & 0.00 & 0.03 \\
\hline \multirow{2}{*}{ Taxa } & \multicolumn{6}{|c|}{$675 p \mathrm{CO}_{2}$ (Day of the experiment) } & \multicolumn{6}{|c|}{$860 \mathrm{pCO}_{2}$ (Day of the experiment) } & \multicolumn{6}{|c|}{$1085 p \mathrm{CO}_{2}$ (Day of the experiment) } \\
\hline & 0 & 7 & 13 & 19 & 25 & 29 & 0 & 7 & 13 & 19 & 25 & 29 & 0 & 7 & 13 & 19 & 25 & 29 \\
\hline Gyrodinium cf. fusiforme & 5.32 & 4.36 & 0.80 & 1.68 & 1.92 & 0.58 & 4.55 & 2.70 & 0.98 & 1.74 & 1.76 & 0.29 & 5.00 & 3.10 & 1.44 & 1.48 & 0.90 & 0.10 \\
\hline odinium cf. arcticum & 3.80 & 4.54 & 1.18 & 2.72 & 2.62 & 2.92 & 2.06 & 3.46 & 1.30 & 2.66 & 3.89 & 2.27 & 3.54 & 3.24 & 2.54 & 4.64 & 2.54 & 1.12 \\
\hline Katodinium cf. glaucum & 0.70 & 0.64 & 1.26 & 4.16 & 4.26 & 2.38 & 0.48 & 0.98 & 1.18 & 4.00 & 3.34 & 1.42 & 0.72 & 1.33 & 0.94 & 3.72 & 3.40 & 1.10 \\
\hline Protoperidinium cf. pellucidum & 0.02 & 0.00 & 0.02 & 0.00 & 0.10 & 0.22 & 0.01 & 0.00 & 0.00 & 0.02 & 0.06 & 0.14 & 0.02 & 0.02 & 0.00 & 0.00 & 0.14 & 0.09 \\
\hline Protoperidinium cf. brevipes & 0.04 & 0.10 & 0.12 & 0.10 & 0.18 & 0.08 & 0.04 & 0.10 & 0.04 & 0.16 & 0.04 & 0.05 & 0.00 & 0.12 & 0.10 & 0.14 & 0.14 & 0.05 \\
\hline Protoperidinium cf. ovatum & 0.18 & 0.08 & 0.10 & 0.16 & 0.14 & 0.12 & 0.15 & 0.14 & 0.28 & 0.00 & 0.06 & 0.15 & 0.18 & 0.18 & 0.18 & 0.20 & 0.14 & 0.00 \\
\hline Strombidium cf. $c$ & 0.26 & 0.24 & 0.42 & 0.40 & 0.00 & 0.00 & 0.07 & 0.14 & 0.64 & 0.08 & 0.14 & 0.10 & 0.18 & 0.34 & 0.86 & 0.22 & 0.22 & 0.07 \\
\hline Strombidium capitatum & 0.60 & 0.28 & 0.08 & 0.08 & 0.00 & 0.02 & 0.51 & 0.18 & 0.06 & 0.00 & 0.00 & 0.01 & 0.30 & 0.16 & 0.08 & 0.30 & 0.06 & 0.00 \\
\hline Cyst Strombidium capitatum & 0.58 & 0.10 & 0.04 & 0.16 & 0.12 & 0.00 & 0.21 & 0.14 & 0.08 & 0.00 & 0.00 & 0.06 & 0.36 & 0.04 & 0.02 & 0.02 & 0.16 & 0.00 \\
\hline Strombidium spp. & 6.84 & 3.00 & 0.14 & 0.12 & 0.00 & 0.00 & 0.89 & 2.56 & 0.12 & 0.06 & 0.02 & 0.00 & 5.20 & 5.32 & 0.48 & 0.40 & 0.62 & 0.03 \\
\hline Rimostrombidium sp. & 0.00 & 0.08 & 0.04 & 0.28 & 0.10 & 0.02 & 0.05 & 0.16 & 0.00 & 0.10 & 0.08 & 0.10 & 0.00 & 0.08 & 0.12 & 0.19 & 0.50 & 0.03 \\
\hline Lohmaniella oviformis & 0.30 & 0.26 & 0.10 & 0.44 & 0.00 & 0.98 & 0.15 & 0.36 & 0.18 & 1.54 & 1.12 & 0.45 & 0.24 & 0.22 & 0.76 & 1.54 & 1.78 & 0.05 \\
\hline Myrionecta rubra & 0.22 & 0.04 & 0.06 & 0.00 & 0.00 & 0.00 & 0.73 & 0.04 & 0.04 & 0.00 & 0.00 & 0.00 & 0.24 & 0.00 & 0.00 & 0.00 & 0.06 & 0.00 \\
\hline Strobilidium spiralis & 0.10 & 0.10 & 0.10 & 0.36 & 0.18 & 0.08 & 0.01 & 0.10 & 0.04 & 0.28 & 0.22 & 0.05 & 0.06 & 0.04 & 0.10 & 0.12 & 0.58 & 0.05 \\
\hline Laboea strobila & 0.14 & 0.06 & 0.00 & 0.28 & 0.12 & 0.00 & 0.01 & 0.14 & 0.04 & 0.18 & 0.00 & 0.12 & 0.22 & 0.08 & 0.04 & 0.04 & 0.10 & 0.00 \\
\hline
\end{tabular}

During the second and the third phase of bloom development, increases in MZP biomass were observed at all $p \mathrm{CO}_{2}$ levels. This corresponds well to the high nanophytoplankton biomass (mainly prasinophytes, autotrophic dinoflagellates and haptophytes; see Schulz et al., 2013 for details) during the second half of the experiment (phase 2 and 3). In addition, high MZP grazing rates on pico- and nanophytoplankton were observed during the phases after nutrient addition from day 13 on (Brussaard et al., 2013). But despite a continuously high pico- and nanophytoplankton availabil- ity and an increasing biomass of autotrophic dinoflagellates (mainly $H$. rotundata), MZP showed a rapid decline during the third phase of bloom development. This phenomenon is most likely not bottom-up regulated but related to an enhanced top-down control of MZP by mesozooplankton. In our study the mesozooplankton were comprised of Cirripedia and copepod nauplii initially and shifted towards a community dominated by polychaete larvae and copepodites (mainly Calanus spp.) from day 18 onwards at all $p \mathrm{CO}_{2}$ levels (Niehoff et al., 2012). Cirripedia larvae, which dominated 
the mesozooplankton clearly during the first phase of bloom development, are characterized by an herbivorous feeding mode in contrast to other meroplanktonic larvae such as copepod nauplii (Turner et al., 2001). This might explain the high initial MZP biomass in the mesocosms when predation pressure by omnivorous mesozooplankton was still low. Subsequently, polychaete larvae and Calanus copepodites, effective grazers of MZP (Turner et al., 2001), became highly abundant, thus pointing to a suppression of MZP by mesozooplankton.

In conclusion, our hypotheses that a high $p \mathrm{CO}_{2}$ will alter MZP community structure, carrying capacity or phenology must be rejected on the basis of the present mesocosm experiment and it points to a relatively high robustness of MZP towards elevated $\mathrm{CO}_{2}$ in coastal waters.

Acknowledgements. This work is a contribution to the "European Project on Ocean Acidification" (EPOCA), which received funding from the European Community's Seventh Framework Programme (FP7/2007-2013) under grant agreement no. 211384. We gratefully acknowledge the logistical support of Greenpeace International for its assistance with the transport of the mesocosm facility from Kiel to Ny-Ålesund and back to Kiel. We also thank the captains and crews of M/V Esperanza of Greenpeace and R/V Viking Explorer of the University Centre in Svalbard (UNIS) for assistance during mesocosm transport and during deployment and recovery in Kongsfjorden. We thank the staff of the French-German Arctic Research Base at Ny-Ålesund, in particular Marcus Schumacher, for on-site logistical support.

Edited by: T. F. Thingstad

\section{References}

Aberle, N., Lengfellner, K., and Sommer, U.: Spring bloom succession, grazing impact and herbivore selectivity of ciliate communities in response to winter warming, Oecologia, 150, 668-681, 2007.

Brussaard, C. P. D., Noordeloos, A. A. M., Witte, H., Collenteur, M. C. J., Schulz, K., Ludwig, A., and Riebesell, U.: Arctic microbial community dynamics influenced by elevated $\mathrm{CO}_{2}$ levels, Biogeosciences, 10, 719-731, doi:10.5194/bg-10-719-2013, 2013.

Calbet, A. and Landry, M. R.: Phytoplankton growth, microzooplankton grazing, and carbon cycling in marine systems, Limnol. Oceanogr., 49, 51-57, 2004.

Calbet, A. and Saiz, E.: The ciliate-copepod link in marine ecosystems, Aquat. Microb. Ecol., 38, 157-167, 2005.

Eilertsen, H. C., Taasen, J. P., and Weslawski, J. M.: Phytoplankton studies in the fjords of West Spitzbergen - physical-environment and production in spring and summer, J. Plankton Res., 11, 1245-1260, 1989.

Feng, Y. Y., Hare, C. E., Leblanc, K., Rose, J. M., Zhang, Y. H., DiTullio, G. R., Lee, P. A., Wilhelm, S. W., Rowe, J. M., Sun, J., Nemcek, N., Gueguen, C., Passow, U., Benner, I., Brown, C., and Hutchins, D. A.: Effects of increased $p \mathrm{CO}_{2}$ and temperature on the North Atlantic spring bloom. I. The phytoplankton com- munity and biogeochemical response, Mar. Ecol.-Prog Ser., 388, 13-25, 2009.

Foissner, W., Berger, H., and Kohmann, F.: Taxonomische und ökologische Revision der Ciliaten des Saprobiensystems Band IIV, edited by: Wasserwirtschaft, I. B. L. f., Informationsberichte Bayerisches Landesamt für Wasserwirtschaft, München, 1991, 1992, 1994, 1995.

Hansen, P. J.: Effect of high pH on the growth and survival of marine phytoplankton: implications for species succession, Aquat. Microb. Ecol., 28, 279-288, 2002.

Hillebrand, H., Duerselen, C.-D., Kirschtel, D., Pollingher, U., and Zohary, T.: Biovolume calculation for pelagic and benthic microalgae, J. Phycol., 35, 403-424, 1999.

Hinga, K. R.: Co-occurrence of dinoflagellate blooms and high $\mathrm{pH}$ in marine enclosures, Mar. Ecol.-Prog Ser., 86, 181-187, 1992.

Hinga, K. R.: Effects of $\mathrm{pH}$ on coastal marine phytoplankton, Mar. Ecol.-Prog Ser., 238, 281-300, 2002.

Hodal, H., Falk-Petersen, S., Hop, H., Kristiansen, S., and Reigstad, M.: Spring bloom dynamics in kongsfjorden, svalbard: Nutrients, phytoplankton, protozoans and primary production, Polar Biol., 35, 191-203, doi:10.1007/s00300-011-1053-7, 2012.

Hop, H., Pearson, T., Hegseth, E. N., Kovacs, K. M., Wiencke, C., Kwasniewski, S., Eiane, K., Mehlum, F., Gulliksen, B., Wlodarska-Kowalezuk, M., Lydersen, C., Weslawski, J. M., Cochrane, S., Gabrielsen, G. W., Leakey, R. J. G., Lonne, O. J., Zajaczkowski, M., Falk-Petersen, S., Kendall, M., Wangberg, S. A., Bischof, K., Voronkov, A. Y., Kovaltchouk, N. A., Wiktor, J., Poltermann, M., di Prisco, G., Papucci, C., and Gerland, S.: The marine ecosystem of Kongsfjorden, Svalbard, Polar Res., 21, 167-208, 2002.

Hoppenrath, M., Elbrächter, M., and Drebes, G.: Marine Phytoplankton, Schweizerbart'Sche Verlagsbuchhandlung, Stuttgart, 2009.

Irigoien, X., Flynn, K. J., and Harris, R. P.: Phytoplankton blooms: a "loophole" in microzooplankton grazing impact?, J. Plankton Res., 27, 313-321, 2005.

Johansson, M., Gorokhova, E., and Larsson, U.: Annual variability in ciliate community structure, potential prey and predators in the open northern Baltic Sea proper, J. Plankton Res., 26, 67-80, 2004.

Kahl, A.: Urtiere oder Protozoa I. Wimpertiere oder Ciliata (Infusoria), in: Tierwelt Deutschlands und der angrenzenden Meeresteile, edited by: Dahl, F., 886 pp., 1932.

Kraberg, A., Baumann, M., and Dürselen, C.: Coastal phytoplankton: Photo guide for Northern Europena Seas, Pfeil Verlag, München, 204 pp., 2010.

Landry, M. R. and Calbet, A.: Microzooplankton production in the oceans, ICES J. Mar. Sci., 61, 501-507, 2004.

Levinsen, H. and Nielsen, T. G.: The trophic role of marine pelagic ciliates and heterotrophic dinoflagellates in arctic and temperate coastal ecosystems: A cross-latitude comparison, Limnol. Oceanogr., 47, 427-439, 2002.

Levinsen, H., Nielsen, T. G., and Hansen, B. W.: Annual succession of marine pelagic protozoans in disko bay, west greenland, with emphasis on winter dynamics, Mar. Ecol.-Prog. Ser., 206, 119134, doi:10.3354/meps206119, 2000.

Loeder, M. G. J., Meunier, C., Wiltshire, K. H., Boersma, M., and Aberle, N.: The role of ciliates, heterotrophic dinoflagellates and copepods in structuring spring plankton communities at Hel- 
goland Roads, North Sea, Mar. Biol., 158, 1551-1580, 2011.

Menden-Deuer, S. and Lessard, E. J.: Carbon to volume relationships for dinoflagellates, diatoms, and other protist plankton, Limnol. Oceanogr., 45, 569-579, 2000.

Niehoff, B., Knüppel, N., Daase, M., Czerny, J., and Boxhammer, T.: Mesozooplankton community development at elevated $\mathrm{CO}_{2}$ concentrations: results from a mesocosm experiment in an Arctic fjord, Biogeosciences Discuss., 9, 11479-11515, doi:10.5194/bgd-9-11479-2012, 2012.

Nielsen, L. T., Jakobsen, H. H., and Hansen, P. J.: High resilience of two coastal plankton communities to twenty-first century seawater acidification: Evidence from microcosm studies, Mar. Biol. Res., 6, 542-555, 2010.

Nielsen, L. T., Hallegraeff, G. M., Wright, S. W., and Hansen, P. J.: Effects of experimental seawater acidification on an estuarine plankton community, Aquat. Microb. Ecol., 65, 271-285, 2012.

Nimer, N. A., Brownlee, C., and Merrett, M. J.: Carbon-dioxide availability intracellular $\mathrm{pH}$ and growth rate of the coccolithophore Emiliana huxleyi, Mar. Ecol.-Prog Ser., 109, 257-262, 1994.

Olenina, I., Hajdu, S., Edler, L., Andersson, A., Wasmund, N., Busch, S., Göbel, J., Gromisz, S., Huseby, S., Huttunen, M., Jaanus, A., Kokkonen, P., Ledaine, I., and Niemkiewicz: Biovolumes and size classes of phytoplankton in the Baltic Sea, HELCOM Balt, Sea Environ. Proc., 106, 144 pp., 2006.

Pedersen, M. F.: Effects of $\mathrm{pH}$ on the growth and survival of six marine heterotrophic protists, Mar. Ecol.-Prog Ser., 260, 33-41, 2003.

Pedersen, M. F. and Hansen, P. J.: Effects of high pH on the growth and survival of six marine heterotrophic protists, Mar. Ecol.-Prog Ser., 260, 33-41, 2003.

Putt, M., and Stoecker, D. K.: An experimentally determined carbon:volume ratio for marine "oligotrichous" ciliates from estuarine and coastal waters, Limnol. Oceanogr., 34, 1097-1103, 1989.

Riebesell, U. and Tortell, P. D.: Effects of ocean acidification on pelagic organisms and ecosystems, in: Ocean Acidification, edited by: Gattuso, J.-P., Hansson, L., Oxford University Press, Oxford, 99-121, 2011.

Riebesell, U., Schulz, K. G., Bellerby, R. G. J., Botros, M., Fritsche, P., Meyerhoefer, M., Neill, C., Nondal, G., Oschlies, A., Wohlers, J., and Zoellner, E.: Enhanced biological carbon consumption in a high $\mathrm{CO}_{2}$ ocean, Nature, 450, 545-548, 2007.

Riebesell, U., Czerny, J., von Bröckel, K., Boxhammer, T., Büdenbender, J., Deckelnick, M., Fischer, M., Hoffmann, D., Krug, S. A., Lentz, U., Ludwig, A., Muche, R., and Schulz, K. G.: Technical Note: A mobile sea-going mesocosm system - new opportunities for ocean change research, Biogeosciences Discuss., 9, 12985-13017, doi:10.5194/bgd-9-12985-2012, 2012.

Rose, J. M., Feng, Y. Y., Gobler, C. J., Gutierrez, R., Hare, C. E., Leblanc, K., and Hutchins, D. A.: Effects of increased $\mathrm{pCO}_{2}$ and temperature on the North Atlantic spring bloom: II. Microzooplankton abundance and grazing, Mar. Ecol.-Prog Ser., 388, $27-$ 40, 2009.

Rossoll, D., Bermundez, R., Hauss, H., Schulz, K. G., Riebesell, U., Sommer, U., and Winder, M.: Ocean acidification-induced food quality deterioration constrains trophic transfer, PLoS one, 7, e34737, doi:10.1371/journal.pone.0034737, 2012.
Sabine, C. L., Feely, R. A., Gruber, N., Key, R. M., Lee, K., Bullister, J. L., Wanninkhof, R., Wong, C. S., Wallace, D. W. R., Tilbrook, B., Millero, F. J., Peng, T. H., Kozyr, A., Ono, T., and Rios, A. F.: The oceanic sink for anthropogenic $\mathrm{CO}_{2}$, Science, 305, 367-371, 2004.

Schulz, K. G., Bellerby, R. G. J., Brussaard, C. P. D., Büdenbender, J., Czerny, J., Engel, A., Fischer, M., Koch-Klavsen, S., Krug, S. A., Lischka, S., Ludwig, A., Meyerhöfer, M., Nondal, G., Silyakova, A., Stuhr, A., and Riebesell, U.: Temporal biomass dynamics of an Arctic plankton bloom in response to increasing levels of atmospheric carbon dioxide, Biogeosciences, 10, 161180, doi:10.5194/bg-10-161-2013, 2013.

Scott, F. J. E.: Antarctic marine protists, edited by: Scott, F. J. E., ABRS, Canberra, Australia, 563 pp., 2005.

Seuthe, L., Iversen, K. R., and Narcy, F.: Microbial processes in a high-latitude fjord (Kongsfjorden, Svalbard): II. Ciliates and dinoflagellates, Polar Biol., 34, 751-766, 2011.

Shannon, C. and Weaver, W.: The mathematical theory of commnunication., University of Illinois Press, Urbana, 117 pp., 1963.

Sherr, E. B. and Sherr, B. F.: Heterotrophic dinoflagellates: a significant component of microzooplankton biomass and major grazers of diatoms in the sea, Mar. Ecol.-Prog Ser., 352, 187-197, 2007.

Strüder-Kypke, M. C., Kypke, E. R., Agatha, S., Warwick, J., Montagnes, D. J. S.: Guide to UK coastal planktonic ciliates (http: //www.liv.ac.uk/ciliate/site/index.htm), Copyright 2002 David Montagnes, The University of Liverpool, Port Erin Marine Laboratory, Port Erin, Isle of Man, British Isles IM9 6JA, 2002.

Suffrian, K., Simonelli, P., Nejstgaard, J. C., Putzeys, S., Carotenuto, Y., and Antia, A. N.: Microzooplankton grazing and phytoplankton growth in marine mesocosms with increased $\mathrm{CO}_{2}$ levels, Biogeosciences, 5, 1145-1156, doi:10.5194/bg-5-11452008, 2008.

Suffrian, K., Schulz, K. G., Gutowska, M. A., Riebesell, U., and Bleich, M.: Cellular pH measurements in Emiliania huxleyi reveal pronounced membrane proton permeability, New Phytol., 190, 595-608, 2011.

Tomas, C. R. E.: Identifying marine diatoms and dinoflagellates., edited by: Tomas, C. R. E., Academic Press, Inc., San Diego, California, 598 pp., 1996.

Turner, J. T., Levinsen, H., Nielsen, T. G., and Hansen, B. W.: Zooplankton feeding ecology: grazing on phytoplankton and predation on protozoans by copepod and barnacle nauplii in Disko Bay, West Greenland, Mar. Ecol.-Prog Ser., 221, 209-219, 2001.

Urabe, J. and Waki, N.: Mitigation of adverse effects of rising $\mathrm{CO}_{2}$ on a planktonic herbivore by mixed algal diets, Global Change Biol., 15, 523-531, 2009.

Utermöhl, H.: Zur Vervollkommnung der quantitativen Phytoplankton-Methodik., Mitteilungen der Internationalen Vereinigung für Limnologie, 9, 1-38, 1958.

Welschmeyer, N. A.: Fluorometric analysis of chlorophyll $a$ in the presence of chlorophyll $b$ and pheopigments, Limnol. Oceanogr., 39, 1985-1992, 1994. 